論 説

報 文

\title{
螢石浮選の速度論に関する研究*
}

\author{
麻 生 欣次郎 1 森 祐 行 $^{1}$ \\ 野 寄 剋 彦 ${ }^{2}$ 木 村 哲 夫 ${ }^{3}$ \\ 吉 原 恒 一 4
}

\section{Studies on the Kinetics of Fluorite Flotation}

\author{
Kinjiro ASO, Sukeyuki MORI, Katsuhiko NOYORI, \\ Tetsuo KIMURA and Koichi YOSHIHARA
}

\begin{abstract}
In the earlier work(1) the authors have reported that during the course of flotation operation, different kinds of the order of reaction rate appear with the progress of reaction successively.

In the present paper, an attempt has been made to explain the various models of flotation mechanism and the physical meaning of flotation rate constants on 0th, 1st and 2nd order reaction.

Flotation rate curve of the Fluorite-Sodium oleate system was studied. A graphic representation of the flotation rate to the yield of mineral was drawn in differential form. It was found that during initial stages of flotation, 0th order reaction was predominant which was followed by 1st order reaction and subsequently more higher order reaction.

From the graph, $K_{0}$, the 0 th order rate constant and $K_{1}$, the 1 st order rate constant were obtained, and physical meaning of these constants were discussed in detail. It was observed that the values of $K_{0}$ and $K_{1}$ were found to be decreased when the concentration of sodium oleate used was more than $0.175 \mathrm{~g} / \mathrm{l}$. This may be due to that the increase of the concentration of sodium oleate makes the contact angle of fluorite smaller and the quantity of mineral particles attached to bubble decreases. It was also obserbed that the value of $K_{0}$ decreases, and the value of $K_{1}$ is constant when the height of froth layer increases. This may be due to that in the 0th order reaction, the stability of froth layer is decreased with the increase of the height of froth layer. In the 1st order reaction at the high froth layer, the assumption of a constant saturation of mineral particles in the froth layer may be able to explain this phenomenon from the standpoint of mass balance. The addition of MIBC to sodium loeate $(0.5 \mathrm{~g} / \mathrm{l})$ seems to increase the value of $K_{0}$ and $K_{1}$. The effect of MIBC may be the same as the one of the decrease of sodium oleate.
\end{abstract}

\section{1. はじめに}

著者等はさきに, 浮選速度解析に関し, 浮選速度曲線 を反応次数の変化，つまり， 2 種以上の反応次数をむっ た速度曲線として解析するてとを試みた。そして反応次 数， $0,1,2$ 次のそれぞれの場合についての浮選機構 のモデルとその時の速度定数の意味を説明し，1本の速 度曲線の中で浮選時間の経過に従って, 異なった 2 種以

* 昭和 47 年度日本鉱業会春季大会にて一部講演

* 昭和48年度日本鉣業会春季大会にて一部講演

1 九州大学工学部採鉱学教室

2 東邦亜鉛株式会社

3 元九州大学工学部採鉱学教室

4 三菱金属株式会社 昭和50年 3 月13日受理
上の浮選機構が逐次，現われてくるという考え方を示し $た^{11}$ 。

今回，浮選としては比較的単純な螢石一オレイン酸ソ 一ダ浮選をとりあげ, オレイン酸ソーダ濃度を変えた場 合，フロス層を高くした場合およびオレイン酸ソーダ水 溶液 $(0.5 \mathrm{~g} / \mathrm{l})$ に MIBC (4-メチル・2-ペンタノール) を添加した場合にどのような浮選速度曲線を示すのか, 浮選速度の測定を行なってみた。その結果, 微分形によ る浮選速度の表示法を用い，初期において 0 次反応，つ いで 1 次反応が現われ，その後さらに高次の反応が現わ れることを観察し, 上記の解析法が現実的に妥当な方法 であるととを確めた。さらに，0次および 1 次反応の部 分について，それぞれの速度定数 $K_{0}$ および $K_{1}$ を求め,

No. 54 ('75一春) 
それらがどのように変化するかを調べ，その物理的意味 について若干の推論を行なった。

\section{2. 試㘰}

不二釷業株式会社，平岩鉱山(岐阜県武儀郡上之保村) 産の螢石を次のように調製した。鉣山から採取してきた 品位の高い塊状の螢石鉣石を破砕し，純粋な螢石結晶と 思われる砕片をハンド・ピッキングにより選び出し，メ ノウ乳鉢で粉砕した。フルイ分けによって整粒した後, さらに水中でデカンテーションを行ない微粒子を除き, 乾燥の後，最終的に200〜270メッシュの整粒試料を調製 した。試料は顕微鏡観察，X線回析分析，分光分析およ び化学分析を行ない不純物を調べた。その結果, 不純物 としての鉣物はほとんどが石英であった。化学分析の結 果は $\mathrm{SiO}_{2} 2.75 \%, \mathrm{MgO} 0.66 \%, \mathrm{Ca}$ が $\mathrm{CaO}$ として 69.46\% であった。F の直接分析は行なっていないが不 純物のほとんどが石英であることを考虑して上記の $\mathrm{CaO}$ を $\mathrm{CaF}_{2}$ 亿換算すると $96.70 \%$ の螢石となる。試料 の比重は測定の結果 3.18 であった。

\section{3. 㲾験装置および方法}

実験装置の模式図を第 1 図に示す。浮選セル99はア リル樹脂製のシリンダー型浮選セル（内径 $50 \mathrm{~mm}$, 高さ $200 \mathrm{~mm}$ ) である。韲拌はマグネティック・スターラ (11) で行ない，规拌による渦卷き防止のために取りはずしで きる十字形の邪魔板(15)（厚さ $2 \mathrm{~mm}$, 長さ $50 \mathrm{~mm}$ ) をセ ル内部に差し込んでいる。セルの下部には窒素ガス導入 用として内径 $0.28 \mathrm{~mm} \phi$ の毛細管をうめとんでいる。浮 選セルの上部は単に円筒を切ったままであり，同じ円筒 から切り出された各種の高さの円筒を積み重祆るととに よって自由にフロス層の高さを設定するてとができる。 フロス層を形成した最上部にはセルと同じ径の孔を持つ 正方形のアクリル板（厚さ $10 \mathrm{~mm}, 300 \times 300 \mathrm{~mm}$ )をの廿 る。実験に際し，ての板より上部に形成されたフロスを 所定時間間隔毎に逐次切りとることによって単位時間の 浮揚量を測定して浮選速度を求める。フロスの切取り方 は第 2 図に示すように厚さ $2 \mathrm{~mm}$ のアクリル板で作ら れた箱 $(100 \times 100 \times 50 \mathrm{~mm})$ を 2 個用い，うすく削られ た箱の端をくっつけ合うようにして，なるべく箱の下面

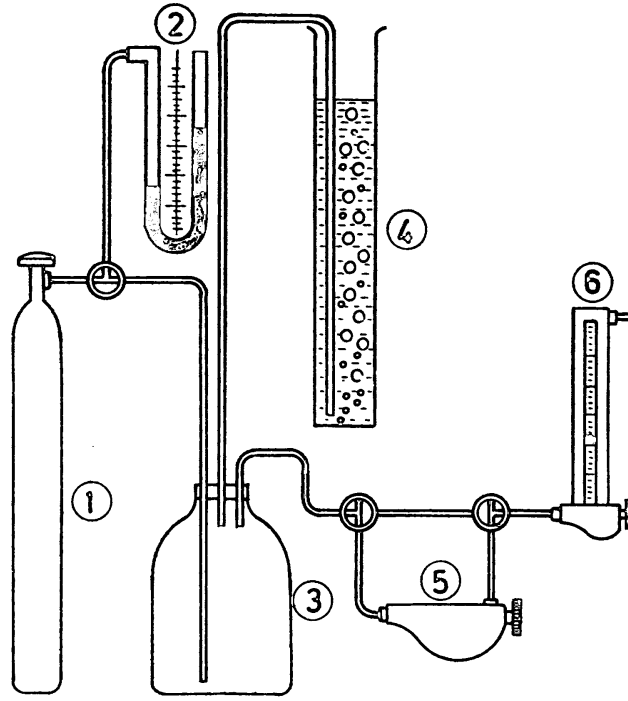

(1) $\mathrm{N}_{2}$ gas bomb.

(2) $\mathrm{Hg}$ manometer.

(3) Receiver.

(4) Pressure regulator.

(5) Needle valve.

(6) Flow meter. (Floai type)

(7) Flow meier. (Soap film)

(8) Manometer. (waier column)

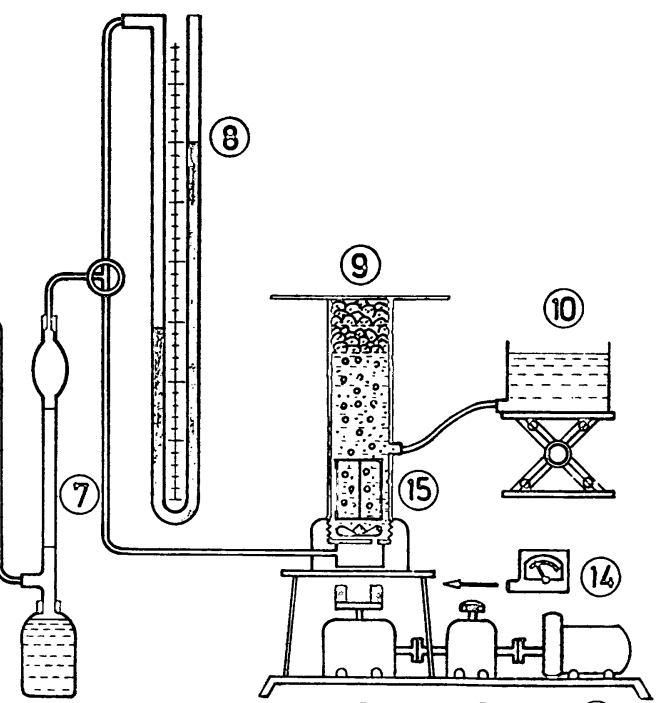

(11)

(13)

(9) Flotation cell.

(10) Regulator of pulp level.

(11) Agitaior.

(12) Speed change gear.

(13) Synchronous moior.

(16) Phoio-eleciric cell iachometer.

(15) Guard plaie. ( to preveni voriex) 


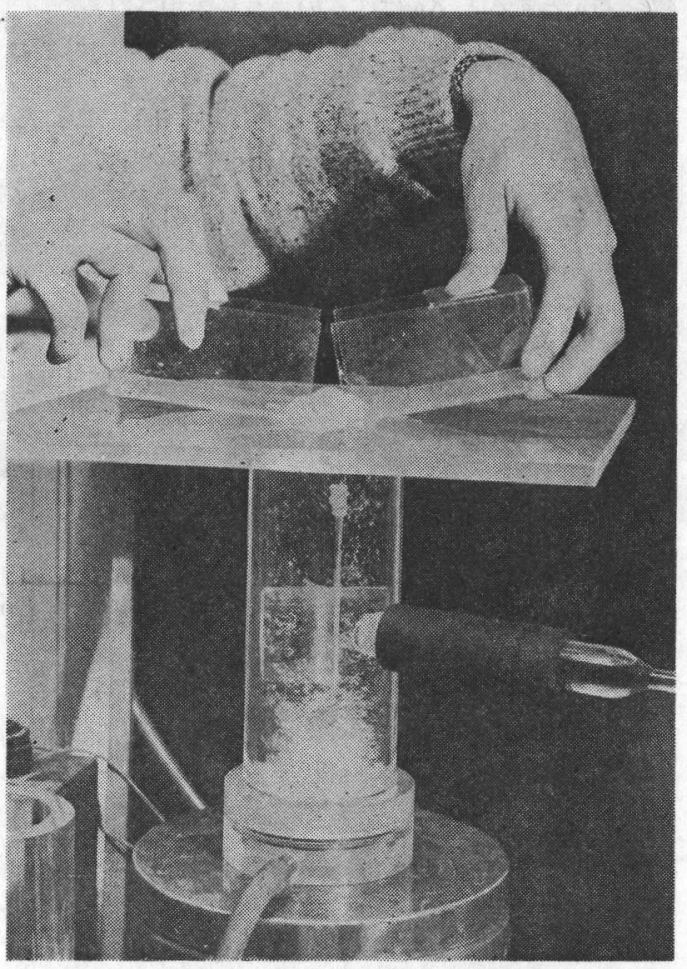

第 2 図 フロス切取りの状態

にフロスが付着しないようにしてフロスを切り取る。切 り取られたフロスは用意されたビーカーに蒸留水で洗浄 しながら移し，ガラス・フィルターでろ過し，乾燥の後， 秤量し浮揚産物の重量を求める。

浮選条件は次に述べるようになるべく条件が一定に保 たれるように努力した。試料 $50 \mathrm{~g}$ と蒸留水 $500 \mathrm{ml}$ を 攪拌容器に入れ，空気が混入しない程度にマグネティッ ク・スターラで攬拌し, 試料を十分に濡らす。その後, 所定のオレイン酸ソーダ溶液あるいは，さらに MIBC を添加した溶液 $500 \mathrm{ml}$ を加えて 10 分程度攪拌する。使 用した試薬は東京化成工業 K. K. 製の E. P. 級試薬であ り，購入に際してはいずれも製造時のロット番号が同一 なむのを求めて, 品質の同一な試薬を使用した。乙の溶 液には $0.05 \mathrm{~N}$ の $\mathrm{NaOH}$ を $20 \mathrm{ml}$ 加えるととにより $\mathrm{pH}$ を11程度で一定になるようにしている。攪拌停止後, 試 料を沈降させ上澄液を 200 ～ $300 \mathrm{ml}$ 洗浄びんに分取す る。条件付けされた武料を残余の溶液と共に浮選セルに そそざ込み, 同時に，あらかじめ分取しておいた上澄液 で試料が残留しないように洗い流しながら浮選セルに全 ての試料を移してしまう。浮選セルの中では試料の注入 と同時に覮拌を始めて, 試料の沈積を防ぐ。ついで, パ ルプ層の液面を浮選セルの上端まで上昇させる。このと き, 試料の一部が水位調節用連通管内に入るととがある
が，これは連通管内の水の流れを注意深く制御して実験 途中でパルプ中に落下しないようにする。マグネティッ ク・スターラの回転数は 600 r. p. m. 程度で一定に調節 している。窒素ガスの流量をあらかじめ約 $50 \mathrm{cc} / \mathrm{min} に$ 設定しておき，ガスの流入を開始して浮選を行なう。実 験中にはガスの流量と圧力をそれぞれ石りん膜流量計(7) と水柱マノメータ(8によって測定している。窒素ガスの 流量調節はレシーバー(3)圧力調整器(4)ならびにニードル バルブ(5によって行なう。

\section{4. 解 析 法}

\section{1 微分形による浮選速度の表示}

速度曲線を取り扱う場合，皘分形として表示するより は微分形の速度曲線として表示する方が数式的, 概念的 にわかりやすい。実験技術の面からいえば積分形として 表示する之第 4, 7，9図にみられるように滑らかな曲線 が得られやすいのに対し，微分形では第 $5,8,10$ 図にみ られるように測定の誤差が大きく表現されるので，より 精密な測定技術が要求されるととになる。しかしながら, 現実的な実験技術として，例えば10分間の測定を行なう 場合に試料採取を 10 分間に 1 回だけまとめて採取する か，それとあ 1 分毎に10回に分割して採取するかという 測定精度の問題であり, 精度よく速度そのものを測定す るように実験をうまく設定するととによって, 解析する に十分な精度で微分形の速度曲線を得ることができる。 また，速度定数を求める場合に，微分形で表示されたグ ラフに捄いては初期残留物量 $\left(W_{i}\right)$ がわからなくてあグ ラフから速度定数を直接求められる利点があり, 微分形 で速度曲線を表示するということは浮選速度を解析する 際の有意義な方法である。

\section{2 反応次数と速度定数}

浮選開始後, 時間 $t(\min )$ までに排出された鉱物の積 算重量 (積算歩留)を $Y(\mathrm{~g})$ ，パルプ中に排出されずに 残留している鉱物の重量を $W(\mathrm{~g})$, 初期残留物重量 (そ の条件下で最終的に浮揚されると考えられる量) を $W_{i}$ （g）とすると次式がなりたつ。

$$
W=W_{i}-Y
$$

浮選速度 $v(\mathrm{~g} / \mathrm{min})$ は次式で表わされる。

$$
v=-d W \mid d t
$$

また (1)式より (2) 式は次式のように表現される。

$$
v=d Y \mid d t
$$

気泡導入量等の浮選条件が一定に保たれると考えれば, $v$ は $W$ あるいは $Y$ の関数と考えられ，次のように表 現される。

No. 54 ('75一春) 


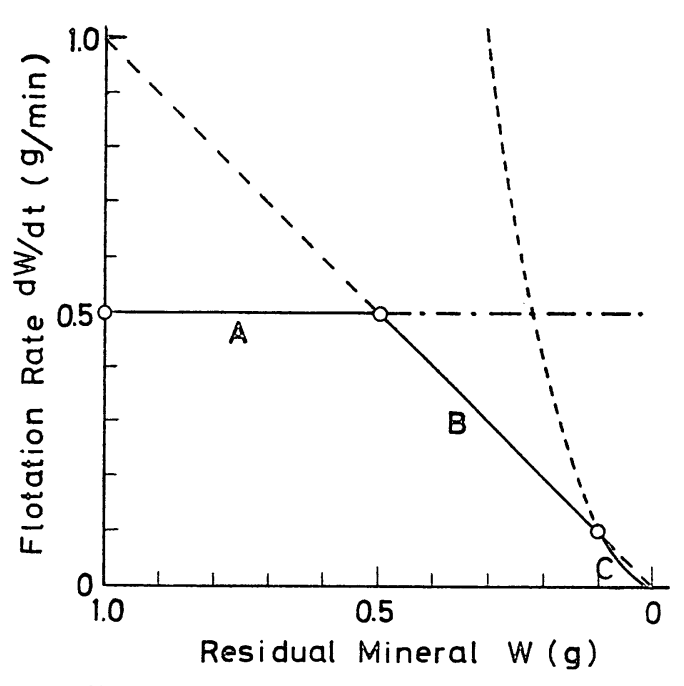

第3 図モデル的な浮選速度曲線（微分形）
A ; 0 次反応 $,-d W / d t=K_{0}, K_{0}=0.5(\mathrm{~g} / \mathrm{min})$
B； 1 次反応, $-d W \mid d t=K_{1} W, K_{1}=1(1 / \mathrm{min})$
C ; 2 次反応, $-d W / d t=K_{2} W^{2}, K_{2}=10(1 / \mathrm{g} \cdot \mathrm{min})$

$$
v=-d W / d t=K_{n} W^{n}
$$

あるいは,

$$
v=d Y \mid d t=K_{n}\left(W_{i}-Y\right)^{n}
$$

ただし， $K_{n}$ は定数である。

速度曲線の解析に当っては $(-d W \mid d t)$ と $W$ あるいは $(d Y \mid d t)$ と $Y$ の関係を実験的に求めることになる。

浮選速度式における反応次数およびその定数のもつ物 理的意味は浮選機構のモデルを設定するととによって定 まる。ひとつのモデルとして，1本の速度曲線の中で，

(4)あるいは (5) 式における $n$ の值が $0,1,2$ と変化した 場合を図示すると第 3 図に示すような速度曲線が得られ る。即ち, $n=0$ では切片 $K_{0}$ の横軸!て平行な直線, $n=$ 1 では勾配 $K_{1}$ の直線， $n=2$ では曲線となる。

各反応次数に対する浮選機構として次のようなモデル が考えられる1)。

i) 0 次反応は鉱粒による気泡の飽和が主要因となっ ている状態。

(4), (5) 式において $n=0$, 第 3 図のA の部分であり,

$$
-d W \mid d t=K_{0}
$$

あるいは,

$$
d Y \mid d t=K_{0}
$$

このとき， $K_{0}$ の内容は次のように考えられる。一定の 大きさの気泡が単位時間当り $N_{B}$ (個 $/ \mathrm{min}$ ) 発生してい る時，1個の泡が設定された条件の下で飽和しうる鉱物 の重量を $k_{B}(\mathrm{~g} /$ 個) とし，フロス層の強さを表わす定
数を $k_{f} 0$ とすると $K_{0}$ は次式のように表現される。

$$
K_{0}=k_{f 0} k_{B} N_{B}
$$

ii) 1 次反応は鉣粒と気泡の衝突が主要因となってい る状態。

(4), (5) 式において $n=1$, 第 3 図の B の部分であり,

$$
-d W / d t=K_{1} W
$$

あるいは，

$$
d Y \mid d t=K_{1}\left(W_{i}-Y\right)
$$

このとき， $K_{1}$ の内容は次のように考えられる。衝笑， 付着の確率を考慮した 1 個の気泡の有効断面積を $A^{*}$ $\left(\mathrm{cm}^{2}\right)$, 単位断面積, 単位時間当りの気泡発生数を $N_{B}$ * (個 $\left./ \mathrm{min} \cdot \mathrm{cm}^{2}\right)$, フロス層に鈗粒が保持される確率をあら わす定数を $k_{f} 1$ とすると $K_{1}$ は次のように表わされる1)。

$$
K_{1}=k_{f 1} A^{*} N_{B}^{*}
$$

iii） 2 次反応は鉱粒と気泡の衙突にさらにフロス層 の強さの影響が加わっている状態。

(4), (5) 式において $n=2$, 第 3 図のCの部分であり,

$$
-d W / d t=K_{2} W^{2}
$$

あるいは，

$$
d Y \mid d t=K_{2}\left(W_{i}-Y\right)^{2}
$$

てのとき， $K_{2}$ の内容は次のように考えられる。フロス 層において鉱粒が保持される確率がフロス層最下部まで 浮揚された鉱粒の量に比例すると仮定し，その比例定数 を $k_{f 2}$ とすると $K_{2}$ は次のように表わされる。

$$
K_{2}=K_{f 2}\left(A^{*} N_{B}\right)^{2}
$$

今， 2 次反応式においてはフロス層に鉱粒が保持される 確率を単純な形に仮定したが，フロスの強さと鉱粒の量 との定量的な関係を撖密に説明することは困難であり， 実際の速度曲線においては厳密に $n=2$ となるというよ りは，むしろ $n>1$ の状態であると考えら机る。

\section{5. 突験結累および考察}

\section{1 オレイン酸ソーダ浸度を変えた場合の速度曲線}

フロス層の高さを $1 \mathrm{~cm}$ に固定し，オレイン酸ソーダ 濃度を変えた場合の速度曲線を第 4 図, 第 5 図に示す. 第 4 図は積分形，第 5 図は微分形である。第 5 図は第 4 図で接線を引くという作図法で求めたものではなくて, 1 分毎に測定された速度の測定值そのものを用いたすの であり,グラフに示されている横軸に平行な多数の線は 各々の区間における平均速度を示している。第 5 図にお ける緃軸は 1 分毎に採取された鉱物の重量, 即ち浮選速 度 $d Y \mid d t(\mathrm{~g} / \mathrm{min})$, 横軸は採取された鉣物の積算重量 $Y$ (g)であり，乙の図は数式的には (7), (10) および (13) 式に対 


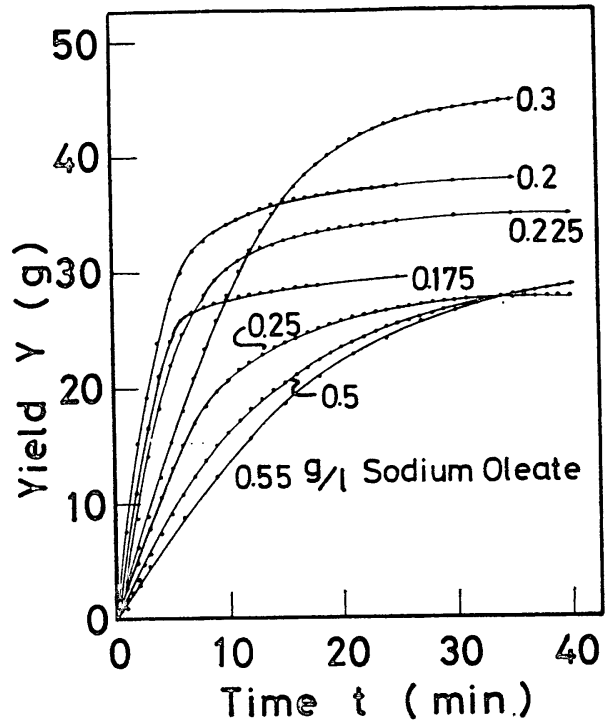

第4図 オレイン酸ソーダ濃度を変えた場合の 浮選速度曲線
応していて，速度曲線の関数形を検討する上において便 利である。

第 4 図には 7 種の実験結果を描いているが第 5 忷は図 が錯綜するのでそのうちの代表的な 4 種を示している。 これらの速度曲線を第 4 章で述べた解析法によって検討 してみると $0.2 \mathrm{~g} / 1$ の場合に顕著に認められるように, 初期の段階で 0 次反応，ついで直線の 1 次反応が現われ， それ以後に曲線の 1 次より高次の反応が現われていると 考えられる。他の濃度の場合においては曲線の部分はそ れほど明瞭ではないが, 直線の 1 次反応の部分は顕著に 現われている。

測定値として得られた第 5 図のグラフから，それを直 線または曲線の合成曲線として表現したものを第 6 図に 示す。オレイン酸ソーダ濃度が減少するにつれて 1 次反 応の部分の勾配（速度定数 $K_{1}$ ） は次第に大きくなって いる。また，横軸に平行な 0 次反応の部分についてもオ レイン酸ソーダ濃度が低下すると速度定数 $K_{0}$ は大きく なっている。1 次より高次の曲線の部分についてはオレ イン酸ソーダの濃度が低い場合に現われているが, 濃度 との関係は明確ではない。

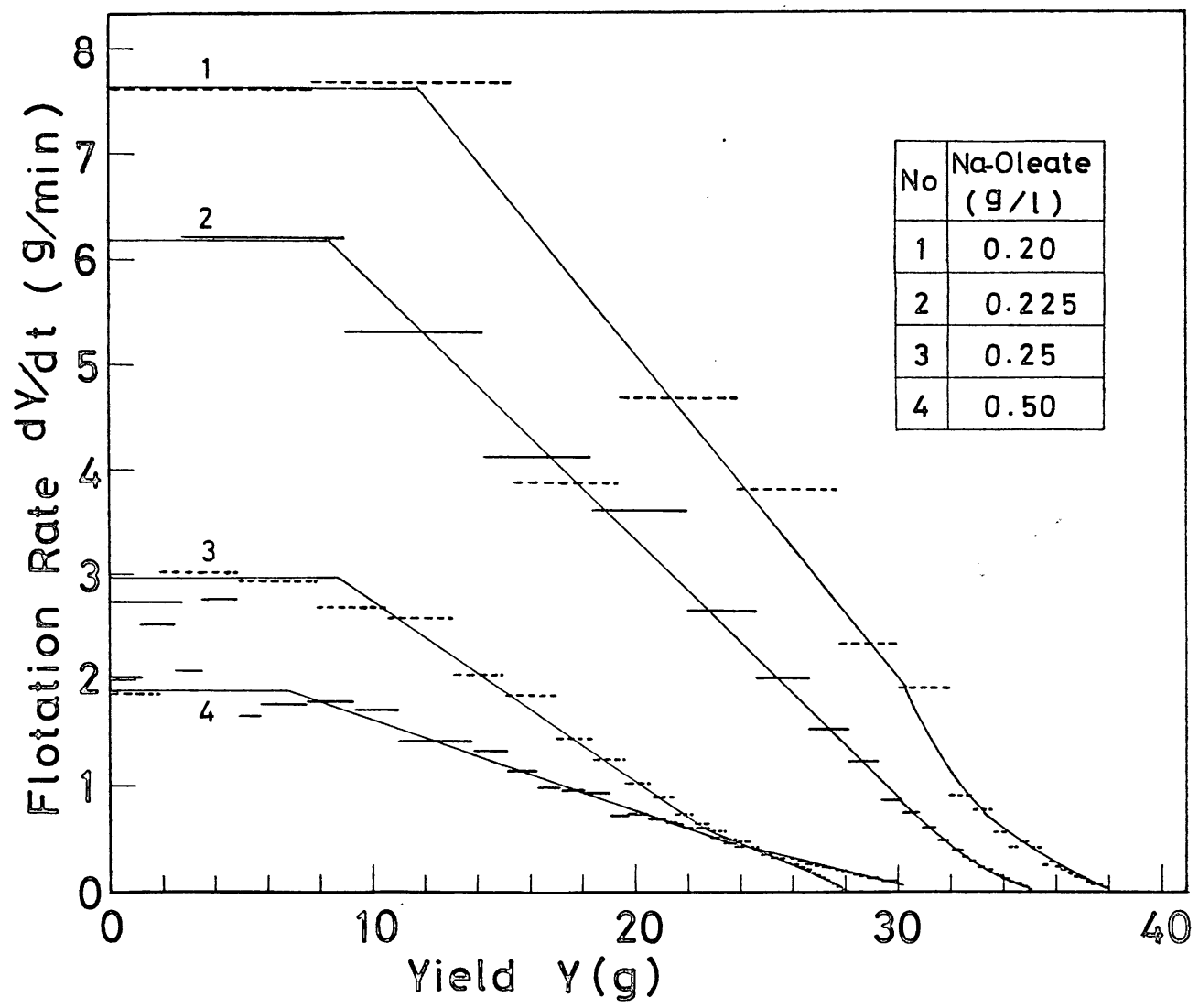

第 5 図 オレイン酸ソーダ濃度を変えた場合の浮選速度曲線 


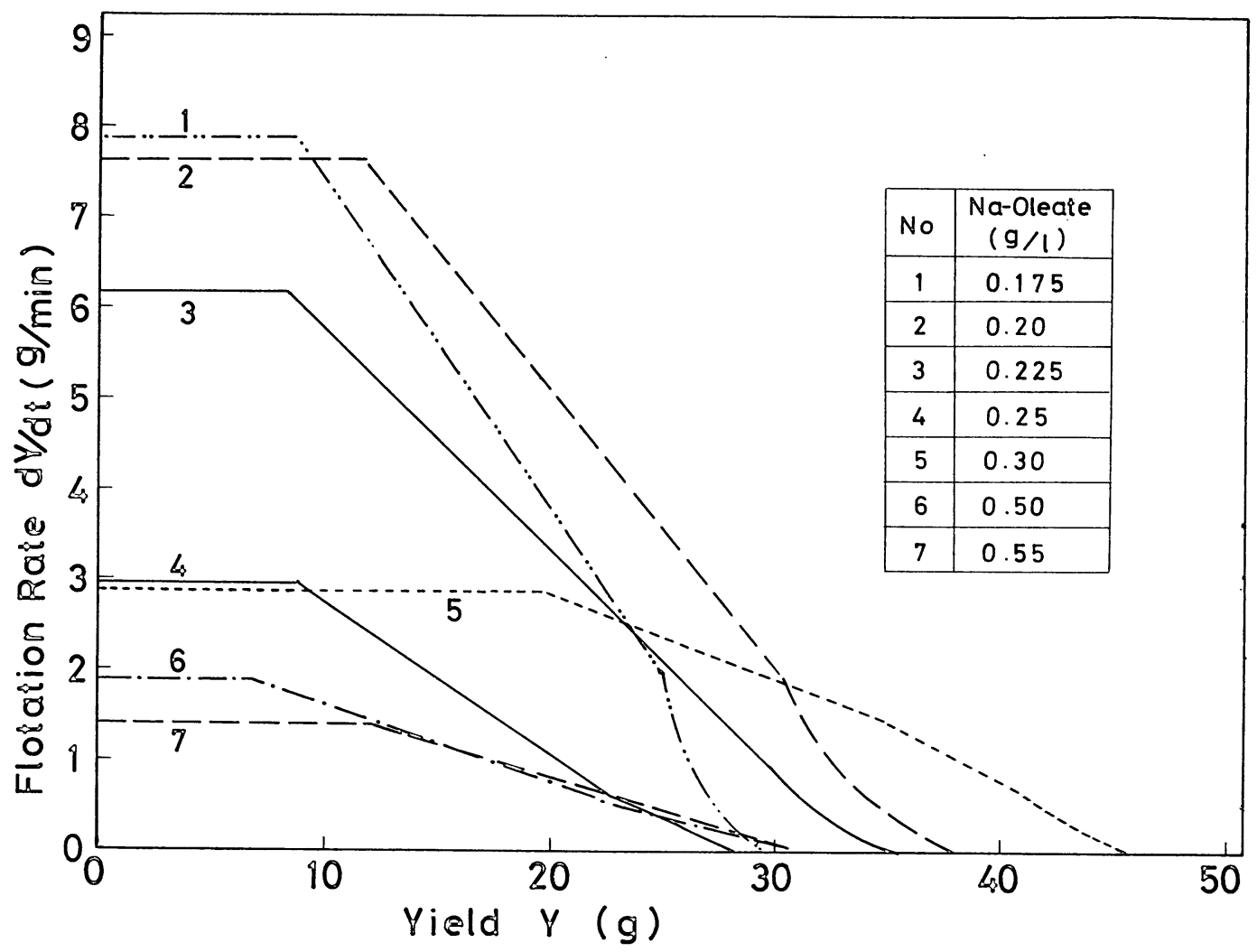

第6 図 オレイン酸ソーダ濃度を変えた場合の浮選速度曲線

0 次反応と考えられる部分について速度定数 $K_{0}$ を， 1 次反応と考えられる部分について速度定数 $K_{1}$ (勾配) を求めて，オレイン酸ソーダ濃度との関係を第 11 図 $(\mathrm{A})$ および第12図 (A) に示した。 $K_{0}, K_{1}$ 共にオレイン酸 ソーダ濃度 $0.3 \mathrm{~g} / \mathrm{l}$ 以上では大きな変化はないが， $0.3 \mathrm{~g} / \mathrm{l}$ 以下の濃度では濃度の減少につれて急激に上昇してい る。オレイン酸ソーダ $0.175 \mathrm{~g} / 1$ より低い濃度ではフロ 層の崩壊が激しくて正確に測定できなかったが, $0.125 \mathrm{~g} / 1$ の場合に $K_{0}$ として $10 \mathrm{~g} / \mathrm{min}$ 程の大きな值が 得られた。

\section{2 フロス層を高くした場合の速度曲線}

オレイン酸ソーダ濃度を $0.5 \mathrm{~g} / \mathrm{l}$ と一定の条件にして, フロス層の高さを $1,6,11,16 \mathrm{~cm}$ に変化させた場合の 速度曲線を第 7 図および第 8 図に示す。第 8 図ではフロ 層 $11 \mathrm{~cm}$ と $16 \mathrm{~cm}$ の場合が錯綜するので $16 \mathrm{~cm}$ の場 合を描いている。フロス層 $16 \mathrm{~cm}$ までは測定するとと ができたが，フロス層をそれ以上高くするとフロス層の 崩壊がひどくなり測定するととができなかった。

第 8 図の速度曲線をみると初期の段階に㨟いて 0 次反 応が現われ，ついで1次反応が現われていると考えられ る。

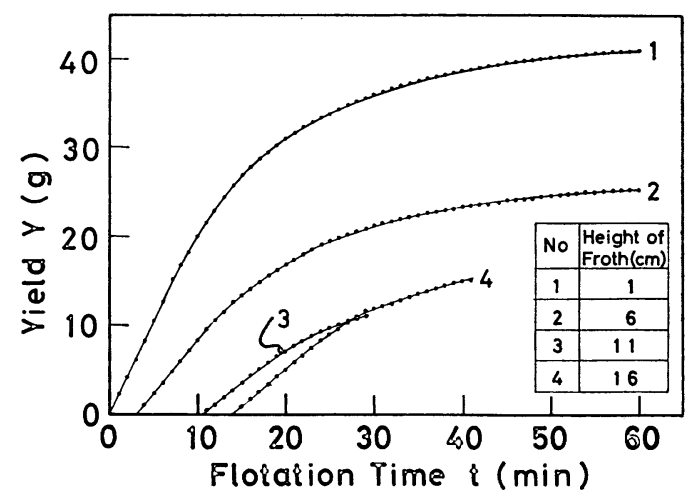

第7図 フロス層を高くした場合の浮選速度曲線

第 8 図から作図により $K_{0}$ および $K_{1}$ を求めてフロス 層の高さと $K_{0}$ および $K_{1}$ の関係を第 11 図 $(\mathrm{B})$ および 第12図 (B) 亿示す。 $K_{\mathbf{0}}$ はフロス層が高くなると，わ ずかではあるが次第に小さな值となっている。 $K_{1}$ には あまり大きな変化はみられず，フロス層を高くしてあ $K_{1}$ は一定と考えられる結果を示している。

\subsection{MIBC を添加した場合の速度曲線}

$0.5 \mathrm{~g} / 1$ のオレイン酸ソーダ水溶液に起泡剂として使用 


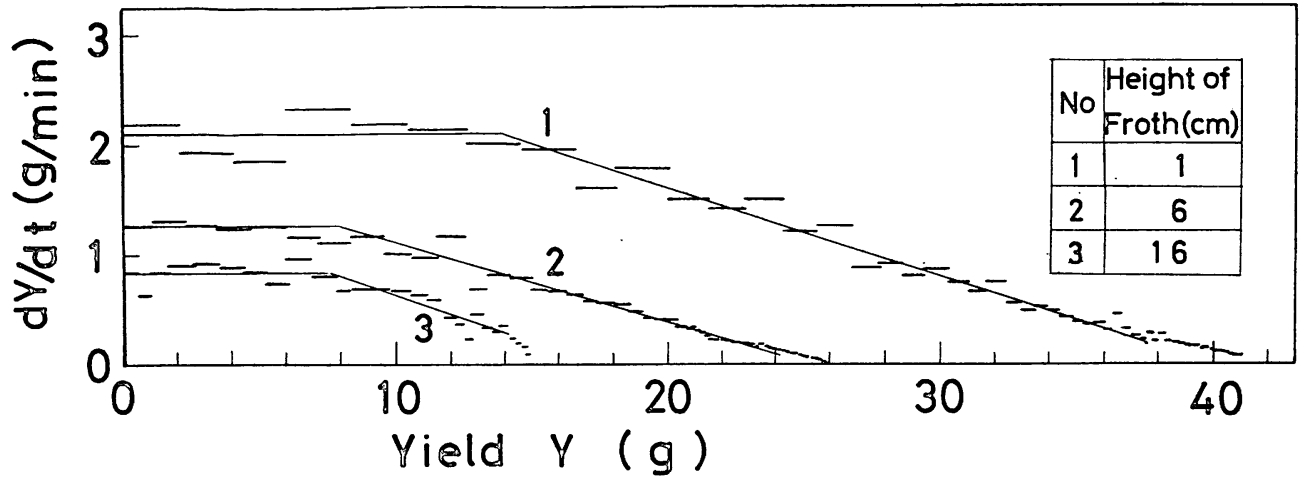

第 8 図フロス層を高くした場合の浮選速度曲線

される MIBC を添加した場合の速度曲線を第 9 図, 第 10図に示す。乙の場合, フロス層は $1 \mathrm{~cm}$ 亿固定してい る。MIBC 添加量 $0,6.5,7.5,8.5 \mathrm{ml} / 1$ の 4 種の速度曲線 を求めたが，第10図には線が錯綜しないように 3 種だけ 表示した。乙れらの速度曲線は明らかに初期の段階で 0 次反応が，それ以後に 1 次反応が現われていると考えら れる。添加量 $7.5 \mathrm{ml} / 1$ の場合には 1 次反応の後でさらに 異なった曲線が現われているようであるが明確ではな い。添加量 $8.5 \mathrm{ml} / \mathrm{l}$ の場合には浮選速度が早くて正確な 測定が困難となり，さらにそれ以上 MIBC を添加する とフロスの崩壊が激しくて測定ができなくなる。

第10図から作図により速度定数 $K_{0}$ および $K_{1}$ を求め て第11図 (C) 拈よび第12図 (C) 飞 MIBC 添加量と

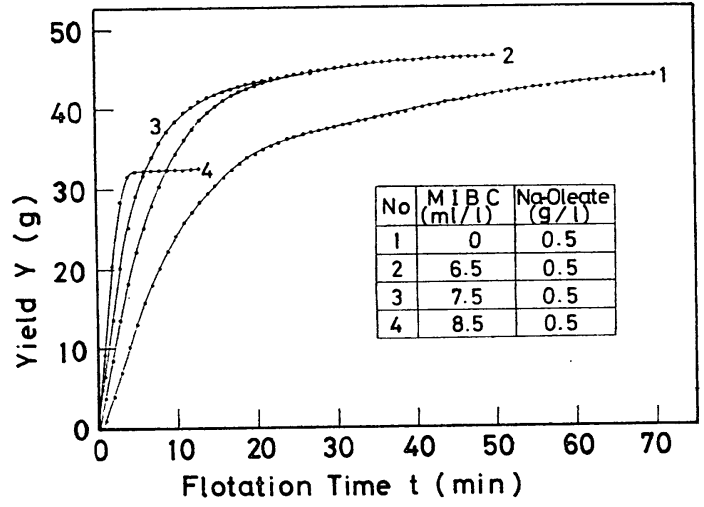

第 9 図 MIBC を添加した場合の浮選速度曲線

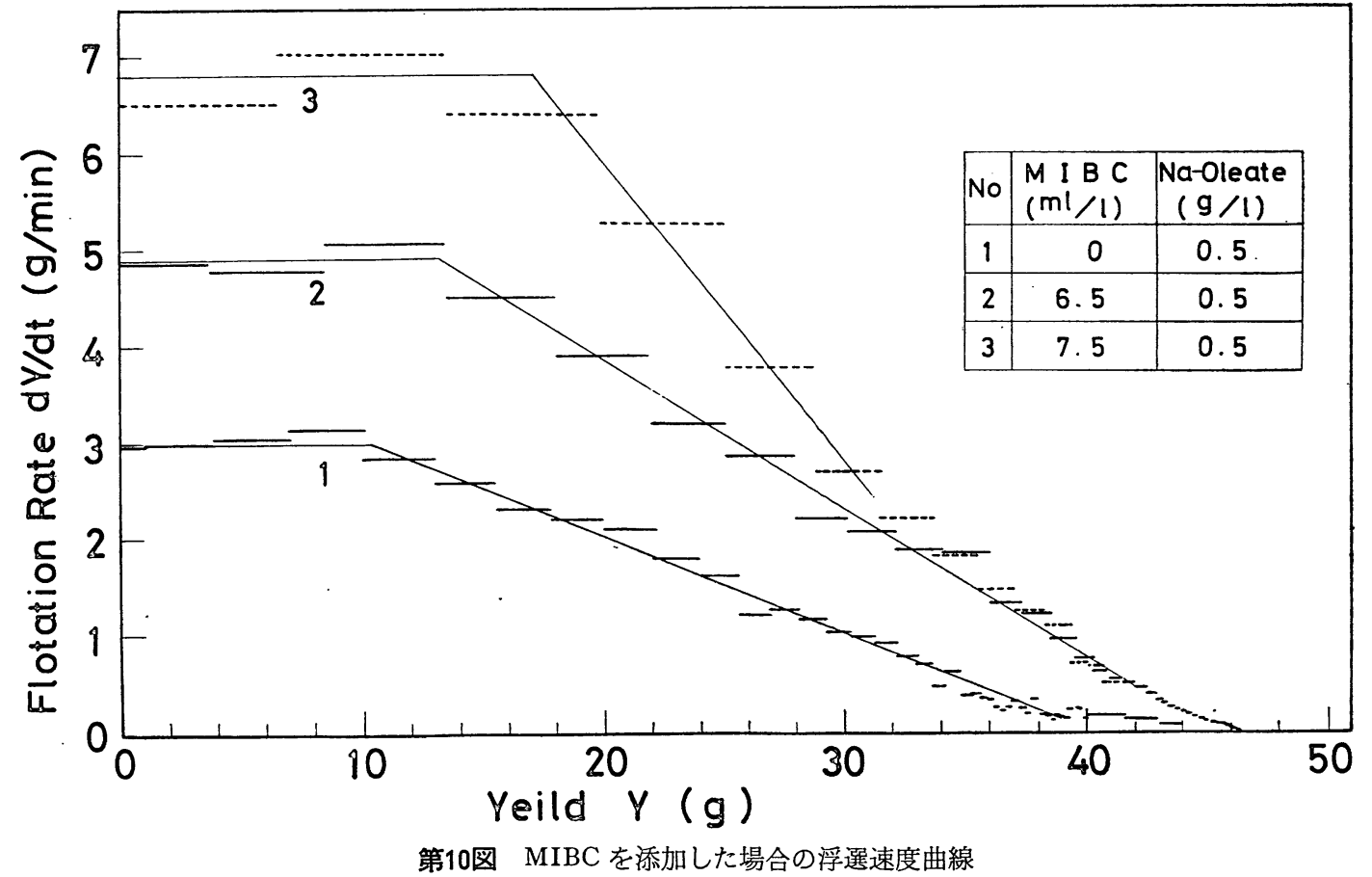

No. 54 ('75一春) 
速度定数の関係を示す。MIBC の添加量が増すと $K_{0}$, $K_{1}$ は共に急激に大きくなる。

\subsection{0 次反応の速度定数 $K_{0}$ の变化に関する考察}

第11図化 0 次反応と思われる部分から求めた速度定数 $K_{0}$ がオレイン酸ソーダ濃度，フロス層の高さおよび $\mathrm{MIBC}$ 添加量とどのような関係にあるかを示す。 $K_{\mathbf{0}}$ は オレイン酸ソーダ濃度を增すと小さくなり，またフロス 層を高くすると小さくなる。そして MIBC の添加量を 増すと $K_{0}$ は大きくなる。本来なら第11図において $(\mathrm{A})$ 図のオレイン酸ソーダ $0.5 \mathrm{~g} / 1$ の点之（B）図のフロス 層の高さ $1 \mathrm{~cm}$ の点之 (C) 図の $\mathrm{MIBC} 0 \mathrm{ml} / \mathrm{l}$ の点か 同一の值を示すべきであるが（A）（B）（C）各々， 測定者, 測定時期が異なったために完全に条件を一定に するととができず，その結果，差がでたすのと思われ る。しかし，各々の一連の実験に找ける相対的な測定值 としては十分満足できる結果が得られていると思われ る。

4.2 節で述べたように $K_{\mathbf{0}}$ の内容は(8) 式の $K_{\mathbf{0}}=$ $k_{f 0} k_{B} N_{B}$ で表わされる。一連の実験㣙いて，単位時 間当りの気泡量 $N_{B}$ (個 $\left./ \mathrm{min}\right)$ はほぼ一定之考えられ る。 $k_{B}$ は 1 個の泡が設定された条件の下で飽和しうる 鉱物の重量 $(\mathrm{g} /$ 個) であり，乙れ住物理的には接触角之 関連している。即ち，接触角が大きくなると 1 個の泡の 表面に支えられる鉣物の量は増大する。

オレイン酸ソーダ濃度を増すと $K_{0}$ が小さくなってい
るとと（第11図（A)）は他の研究で得られた，オレイ ン酸ソーダ濃度が或る濃度以上になると接触角が減少す るという実駼結果2) と一致している。フロス層の高さは 各濃度共 $1 \mathrm{~cm}$ 亿固定しており，フロス層の強さを表わ す定数 $k_{f 0}$ は一定之考えられる。従って，オレイン酸 ソーダ濃度の増大と $K_{0}$ の減少の関係は接触角の減少に より， 1 個の泡の飽和しうる量 $k_{B}(\mathrm{~g} /$ 個）が小さくな っていると解釈するととができる。

フロス層を高くした場合に対しては浮選機構のモデル を次のように考えてみる。パルプ層中において 0 次反忘 で鉱粒に飽和された気泡はそのままフロス層を形成する が，上方へ漸次上昇する際に脱水その他の理由で気泡は 一部破壊さ机ていく。乙のため，破壊によって液膜から 離脱した鉱粒は他のフロスが飽和されているのでフロス 層中を落下していくあの之考えられる。従って，フロス に実際に保持されている鉱粒の量に変化はない。フロス が破壊することによって搔さ出されるフロスの量が減少 するため $K_{\mathbf{0}}$ は小さくなるが，同一フロス層高さでは 0 次反応が現われ，フロス層の高さが大となると破壊され るフロスが多くなるので $K_{\mathbf{0}}$ が小さくなると考えられ る。すなわち， $K_{0}=k_{f 0} k_{B} N_{B}$ において，フロス層に 入ってくる $k_{B} N_{B}$ は一定であるが，フロス層が高くな るとフロス層の破壊によって $k_{f} 0$ が小さくなると考えら れる。このことは他の研究で得られた起泡性試験におい て，フロス層の高さが大となると起泡性が低下するとい う実験結果3) から説明づけられる。

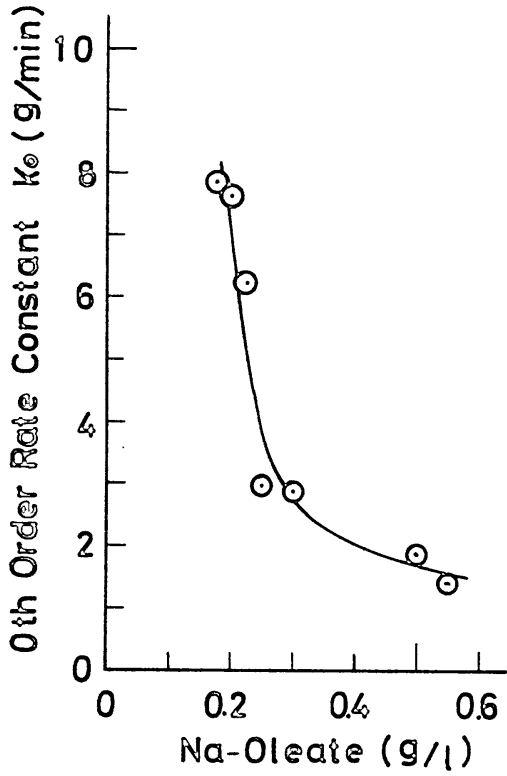

(A)

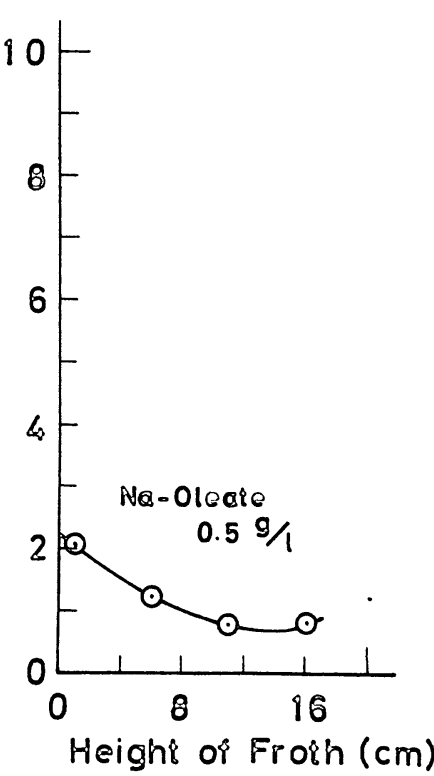

(B)

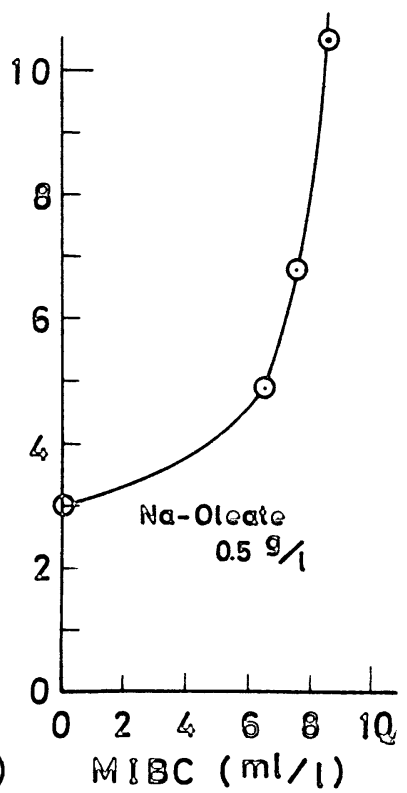

(C)

算11図 0 次反応の速度定数 $K_{0}$ の变化 


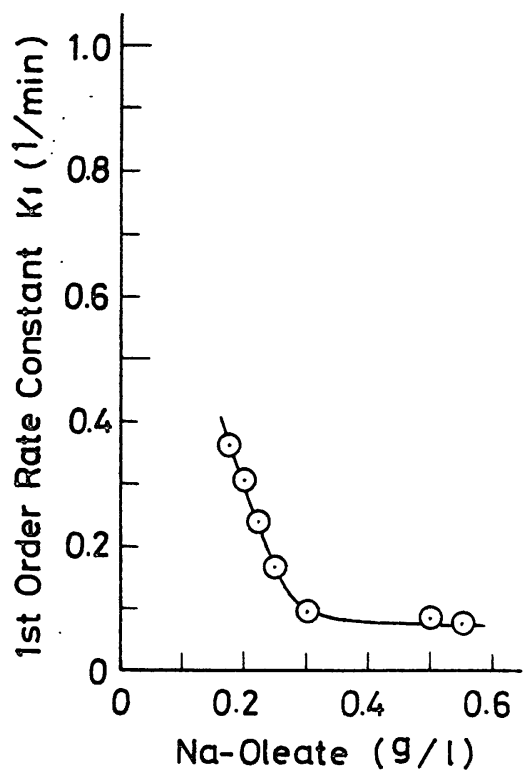

(A)

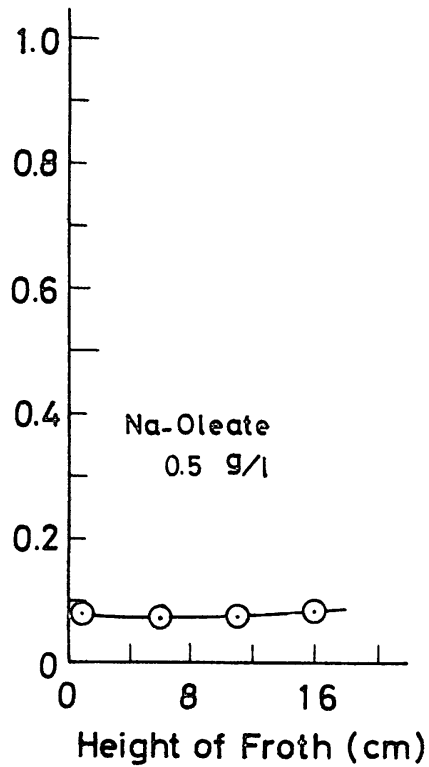

(B)

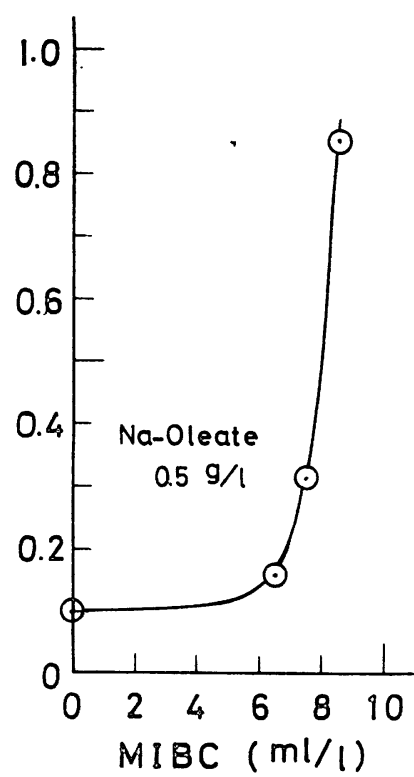

(C)

第12図 1 次反忘の速度定数 $K_{1}$ の变化

起泡剂として使用されている MIBC を添加すると $5 \mathrm{ml} / 1$ 以上で急激に起泡性は低下し, $10 \mathrm{ml} / \mathrm{l}$ 以上でフ ロスの形成ができなくなるという実験結果が他の研究に より得られている3 が， $K_{\mathbf{0}}$ は MIBC を添加すると大 きくなっているてとから，MIBC の添加の影響は 1 個 の泡の飽和量 $k_{B}$ を大きくしているのではないかと考え られる。オレイン酸ソーダ濃度変化の場合から類推すれ ば接触角が増大すると考えられるが，他方 MIBC の添 加は表面張力を上昇させるので，てれの影響屯考えられ る。

\subsection{1 次反応の速度定数 $K_{1}$ の変化に関する考察}

第12図に 1 次反応亡思われる部分から求めた速度定数 $K_{1}$ がオレイン酸ソーダ濃度, フロス層高さおよび MIBC 添加量とどのような関係にあるかを示す。オレ イン酸ソーダ濃度との関係では $0.3 \mathrm{~g} / 1$ 以上の濃度では 大きな変化はないが, $0.3 \mathrm{~g} / 1$ 以下の濃度では濃度の減少 と共に $K_{1}$ は次第に大きくなる。一方, フロス層の高さ を変化させてあ $K_{1}$ は変化せずほほ一定と考えられる。 またオレイン酸ソーダ $0.5 \mathrm{~g} / 1$ の濃度で $\mathrm{MIBC}$ を添加す ると $K_{1}$ が急激に大きくなっている。

$K_{1}$ の内容は (11) 式の $K_{1}=k_{f 1} A^{*} N_{B} *$ で表わされる が，一連の実験において $N_{B}$ *つまり単位断面積, 単位 時間当りの気泡発生量はほぼ一定之考元られる。 $A^{*}$ は 衝突, 付着の確率を考虑した気泡の有効断面積であり, $A^{*}$ が大きくなるということは気泡と鈗粒がより多く気
泡に捕捉されやすくなるということを意味している。乙 れは物理的には接触角が大きくなるととと関連させて考 えるととができる。オレイン酸ソーダ濃度との関係にお いて, 濃度と共に $K_{1}$ が小さくなっていることは 5.4 節 であ述べた $k_{B}$ と同じく濃度と共に接触角が減少するこ とによって, ての $A^{*}$ が小さくなっていると解釈するて とができる。

$k_{f 1}$ はフロス層まで浮掦された鉱粒がフロス層に保持 されて排出される確率を表わしている。即ち, フロス層 に到達した鉱粒は全部フロス層を経て排出される場合に $k_{f 1}=1$ であり, $k_{f 1}=0$ の場合はフロス首に銨粒が到達 してあフロス層に保持されることができず，鉱粒は全く 排出されない場合である。オレイン酸ソーダ濃度を変化 させた実験においてはフロス層の高さを $1 \mathrm{~cm}$ 亿固定し ているので $k_{f} 1$ は一定と考えられ，さらに起泡性実験の 結果3) 加ら考えると $k_{f 1}=1$ と考えられる。乙のような 実験条件においてはパルプ層内で 1 次反応が進行してい る時にはフロス層の最上端であ 1 次反応がそのまま測定 されていると考えられる。

フロス層の高さを高くした埸合に 1 次反応が測定され， しかむ, その速度定数 $K_{1}$ がほとんど变化せず一定であ るととに関しては次のように考えることができる。パル プ層とフロス層の界面で 0 次反応加ら 1 次反応へ変化し た後のフロス層中の鉱粒保持の状態を考えてみると，フ ロスの破壞によってフロス層中を落下する鉱粒が下部の 不飽和（1次反応）のフロス層に達したとき，てれに捕 
捉されると考えると，落下中の鉱粒は別にして，フロス 層は，なお新たな飽和の状態が続くものと考えられる。 落下鉱粒が不飽和フロスを飽和させる以上に存在する場 合にはフロス層上部からの排出はなお 0 次反応として測 定されると考えられるが，余分の落下鉣粒がなくなった 時点ではフロス層全体としてみると，0次反応か測定さ れている時点とは異なってはいるが，新たな飽和状態が な打維持されていると考えられる。パルプ層からは 1 次 反応に基ずく鉱粒の量が補給され，その分だけがフロス 層上部から搔き出されると考えると収支はバランスす る。乙の結果, ある時点から1次反応が表われ， しか 屯，その反応速度定数はパルプ内のそれと一致するあの と考えられる。フロス層高さの如何にかかわらず $K_{1}$ が 一定であることの説明も一応, 以上の仮定のもとに成立 する。第 7 図において各フロス高さの縦軸値の差は各時 間においてフロス層中に保持されている鉱粒の量を表わ していると考えられるが，1 次反応の開始後のての值が ほば一定になっているととは上記の仮説を裏付けている あのと考えられる。

MIBC の添加の影響は前節の $K_{0}$ の考察と同じく, 気 泡の有効断面積 $A *$ を急激に増大させているのではない かとも考えられる。
謝 辞

浮選速度の研究を始めてから既に久しい年月が過ぎ去 った。研究の当初, 熱意ある討論と有益な助言をいただ き，その後も変わら激励をいただいた九州大学理学部 物理学教室, 岡本寿夫博士に厚く御礼申し上げる。また 東京大学, 今泉常正教授, 井上外志雄助教授の浮選速度 論に関する多くの論文によって, 研究に取り組むきっか けをつかみ, 多くの示唆がえられたととを記し, 両博士 に深く敬意を表する。

\section{参苔立歒}

1）麻生欣次郎, 森 犃行：浮選速度解析以関する一考 察, 九大工学集報, V. 40, N. 5, p. 859〜867 (1967)

2) 城戸博児, 森 祐行, 麻生欣次郎: 浮選作用する 支持力について，日本鉱業会誌（投稿中）

3）麻生欣次郎, 森 祐行, 木村哲夫, 吉原恒一:オン イン酸ソーダ水溶液の起泡性に関する実験的研究, 浮選, No. 47, p. 6 10 (1972) 